\title{
The Alternative Model of Controlling Change in Educational Policy Implementation
}

\author{
Aceng Muhtaram Mirfani \\ Universitas Pendidikan Indonesia \\ Jalan Dr. Setiabudhi No. 229 Bandung \\ am_mirfani@up.edu
}

\begin{abstract}
The failure of efforts to change is a common phenomenon, not an exception in the implementation of education policies. The problem is how to keep it for later can be avoided. One of the keys depends on controlling the change effort itself. To find an alternative model of systemic change control, the authors have examined the implementation of basic education capacity development policies that have been implemented since 2003 to 2008 in 20 districts involving 4,244 schools. The study aims to identify the main arguments are suitable for use in developing a model for the management of change. Research using descriptive analysis with a qualitative approach. Data were collected through interviews, observation, and documentation of a number of policy objectives of capacity building, which includes the core committee of the Board of Education at District level, Team School-Based Management Team at District level, Educational Planning Team at District level, the School Committee, Team of School Quality Improvement, and Team of School Rehabilitation. Data analysis was performed on the content of each unit of analysis of the research questions, which is what the essential of controlling, how the mechanism of controlling, and how the controlling actualization of the capacity building at the parties Involved at the district level and the school level? The results of the research were identified six postulates that subsequently to base on the formulation of the controlling, that the proposed change.
\end{abstract}

Keywords-Intervention Components, Devices of Ethical Standards, Setting the Core Component, Cycle Monitoring and Evaluation.

\section{INTRODUCTION}

One of the essences of a policy implementation is conducting the changes. Change is an inevitable, even becomes imperative for an organization to keep and promote its existence to be better than ever. But in reality, the various efforts that have been made many changes that failed than successful (Kotter, 1996; Warrilow, 2010; and Elle, 2011). Failure change can occur in three ways: failure to see, failure to move, and failure to finish (Black and Gregersen, 2006). Therefore, the control function becomes worthy to be promoted to avoid failure. Recently the results of control theory and mechanism design are widely applied to solve management problems in various fields (Burkov et al, 2015). Several studies of the efforts of educational change in Indonesia turned out to show the same tendency (Winarno Surahmad; 1981; Aziz Wahab, 1987; Iim Wasliman, 2002).

The main problem should soon be solved is how to keep the implementation of any policy change in education can be controlled effectively. For the study focused on identifying the appropriate arguments to develop alternative models of educational change control. A model for the management of systemic changes that we have developed contrary to the postulate resulting from a change management perspective study in the capacity building of basic education 2003-2008 (A Study To 'Work Team Substantive' Decentralized Basic Education Project) in Indonesia. The project that operationalized since 2003 to 2008 has involved 4.244 schools at 20 districts. Among the focus of research is related to controlling changes to the substantive teams at the district level that covering Education Planning Team, SBM Developer Team, and the Board of Education, and at the level of school units include Quality Development Team, Rehabilitation Team, and the School Committee. Research questions related to project control has been proposed: How to control the development of the capacity of the units of the organization at the district level and the organizing units at the school level? The specifications include What is the essential component of control, what control mechanisms, and how to control actualization. The study's findings on all these specifications have been discussed with a number of views that are relevant to the context changes (Cameron and Green, 2009; Carnall, 2007; Pettigrew and Whipp, 1991; Rogers, 1983; Ann Salerno and Billie Brock, 2008; Scharmer, 2007).

\section{RESEARCH METHODOLOGY}

Research conducted not intend to test a hypothesis, but to describe and analyze the data so found a general trend that can be used as the material for further study in order to develop alternative control models interchangeability of the project activities. This Research using descriptive analysis method with a qualitative approach. Data were collected through interviews, observation, and documentation of a number of policy objectives of capacity building. This is 
consistent with the view of some authors (Riccucci, 2008; and Yang et al., 2008) agreed that a descriptive-analytic study was designed to obtain information about the status of symptoms when the research is done. Human samples used in this study were more likely to act as informants. Population and sample or as a research subject of organizational units in question are: (1) Chairman and board member of the District Education Planning Team; (2) The Chairman and members of the district management team of School-Based Management; (3) Chairman and board member of the District Education Council; (4) The Chairman and members of the School Quality Improvement Team; (5) The Chairman and members of the School Rehabilitation Team; Chairman and members of the school committee; (7) Changes agents in the district level; and (8) Change agents at the school level. Other subjects determined "snowball", that is, if the researcher wants to obtain in-depth information, the informant advised to contact the informant more competent. Data analysis was performed on the content of each unit of analysis of the research questions, which is what the essential of controlling, how the mechanism of controlling, and how the controlling actualization of the capacity building at the parties Involved at the district level and the school level?

\section{RESEARCH RESULTS}

As for some basic postulates or proposition can be formulated based on the results of this study include the following. Some postulates in line with the view of some experts who study change management (Dean Anderson and Linda Ackerman, 2008; Jeffrey M. Hiatt, 2007; Michael G. Fullan and Stiegelbauer Suzanne, 1991; and Rosabeth Moss Kanter, 1983)

Postulate One:

The effectiveness of change projects affected by the "leadership" change manager who directs the actors and changes targets on the movement of the mental process of adopting distributed innovation.

Postulate Two:

The efficiency of change projects is influenced by the smooth of managerial operation of the project managers that utilize managerial resources necessary project inputs.

Postulate Three:

That a project of educational change that has ethical standards in the system and if applied consistently, the more likely to avoid the failure that comes from the vested interests of stakeholders.

\section{Postulate Four:}

That the control efforts of educational change in line with the values of intrinsic and instrumental values of education can lead to results that true change.
Postulate Five:

That control over change efforts undertaken consciously and consistently by the competent authority in a project, provide greater assurance on efficiency and effectiveness.

Postulate Six:

The greater the risk of non-compliance in the actualization of the actors and change targets roles becomes more urgent control model of an early warning system.

\section{CONCLUSION}

Based on the arguments that have been formulated as described above authors then mixes it with the positioning of each of meaning contained in the argument. For later authors formulate some thoughts that crystallized a framework of "the alternative model of control system change projects" and proposed as "Proposition" for policy improvements in the design and implementation of a change projects in education. The formulations thinking system component in the proposed model includes precepts as follows:

Precept one: There are two groups of intervention components that absolutely must walk in rhythm as a project control function changes, namely professional intervention is decided offender "Change Manager" and the technical intervention was decided offender "Project Manager".

Precept Two: There are three sets of ethical standards that should be early understood by all stakeholders and consistent run, in the form of the "Code of Conduct", "Consequences of Non-Compliance" and "Due Process".

Precept Three: There are three setting the core components of the project framework changes that must be formulated in the dimensions of the load, space and time, which is packaged in the formulation of "Project Outputs", "Inputs Project", and "Time Period".

Precept Four: There are three core components are unified in the dynamics of change projects that should be the target of control, namely the "innovation" of the substance of the charge changes, the "system mechanism" which is the process signals to innovation, and "Change Agent" who acts "conditioning" environment change.

Precept Five: There are two cycles of monitoring and evaluation component that periodically made to intervene in the decision "Change Manager" shaped "Compliance Monitoring" and for intervention "Project Manager" shaped "Progress and Performance Monitoring".

The integration of the five above-mentioned precepts, the authors mapped the "Framework Fruits" research that form the framework of "The Alternative Model of Control System of Change Education Project" that was exhibited as the following picture: 


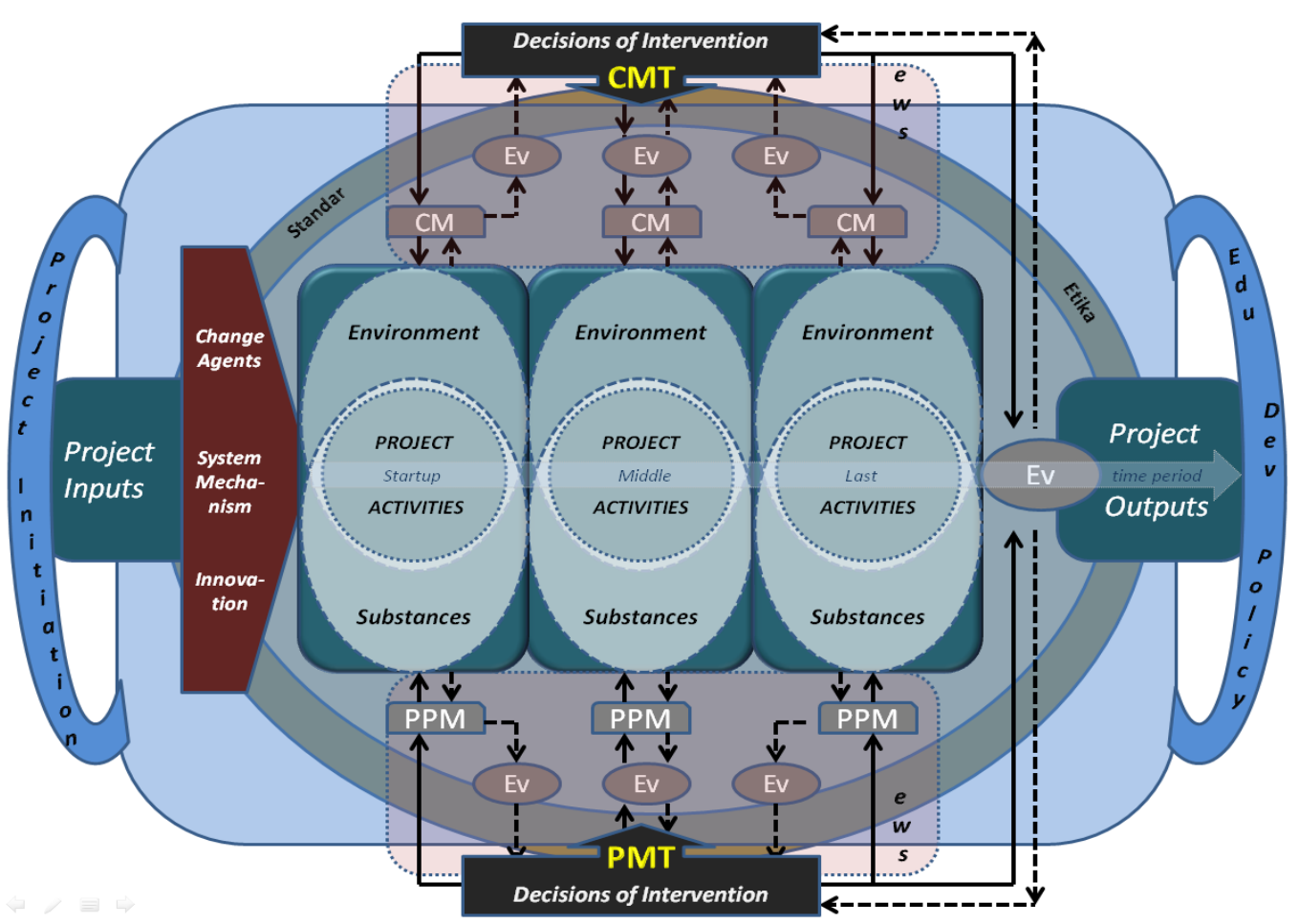

$\mathrm{CMT}=$ Change Manager Team

$\mathrm{CM}=$ Compliance Monitoring

$\mathrm{Ev}=$ Evaluation

$E d u=$ Educational

$\longrightarrow=$ Assignment
PMT $=$ Project Manager Team

PPM $=$ Progress \& Performance monitoring

EWS = Early Warning System

Dev $=$ Development

\section{REFERENCE}

[1] Anderson, Dean and Linda Ackerman (2008): How Command and Control as a Change Leadership Style Causes transformational Change Efforts to Fail;

[2] Black, J. Stewart and Gregersen, Halp B. (2006). Leading Strategic Change Breaking thought The Brain Barrier: Pearson Education, Inc.

[3] Burkov, Vladimir N., cs. (2015). Introduction to Theory of Control in Organizations; Taylor \& Francis Group, LLC

[4] Cameron, Esther and Green, Mike (2009). Making sense of change management : a complete guide to the models, tools and techniques of organizational change, 2nd ed. LondonPhiladelphia; Kogan Page.

[5] Carnall, Colin A. (2007). Managing Change in Organizations (Fifth Edition); Prentice-Hall International, UK

[6] Elle, Klaus (2011) Metaphorical Management Using Intuition and Creativity as a Control Mechanism for Complex Systems; Springer Science+Business Media B.V.

[7] Fullan, Michael G. dan Stiegelbauer, Suzanne (1991) The New Meaning of Educational Change, (2nd Edition), New York: Teacher College Press.

[8] Hiatt, Jeffrey M. (2007): ADKAR: a model for change in business, government and our community - a complete description of the model; Prosci Rsearch
[9] Kanter, Rosabeth Moss (1983): The Change Masters; London, George Allen and Unwin.

[10] Kotter, John P. (2006). "Leading Change: Why Transformation Efforts Fail": Harvard Business Review-HBR OnPoint (C) 2000 by Harvard Business School Publishing.

[11] Pettigrew , A.Y and Whipp, R. (1991). Managing Change for Competitive Success, Oxford: Blackwell publishers.

[12] Rogers, Everett M. (1983). Diffusion of Innovations, third Edition, and New York: Macmillan Publishing Co. Inc.

[13] Riccucci, Norma M. (2008). The Logic of Inquiry in the Field of Public Administration, in Handbook of research methods in public administration/ editors: Gerald J. Miller and Kaifeng Yang; Taylor \& Francis Group, LLC. -- 2nd Ed.

[14] Salerno, Ann and Brock, Billie (2008). The Change Cycle: How People Can Survive and Thrive in Organizational Change; Published by Berrett-Koehler Publisher.

[15] Surakhmad, Winarno (1981), "Problematik Pembaruan Pendidikan Negara-Negara Yang Sedang Berkembang Dewasa Ini”, (Prisma Edisi Perbruari), Jakarta: LP3ES.

[16] Wahab, Abdul Azis (1987): Implementasi Konsep Pendekatan Tujuan dan Cara Belajar Siswa Aktif Oleh Guru SMA Negeri Kabupaten Bandung, Suatu Studi Administrasi Inovasi Pendidikan, Disertasi Doktor (tidak diterbitkan), FPS IKIP Bandung. 
[17] Warrilow, Stephen (2010). Strategies for Managing Change, Lynton Glenthorne Ltd.

[18] Wasliman, Iim (2002): Pengaruh Faktor-Faktor Kondisi Persekolahan Terhadap Efektivitas Sekolah Ditinjau Dari Nilainilai Kebijakan (Studi kebijakan implementasi manajemen berbasis sekolah pada SD dan SLTP Negeri di Jawa Barat). Disertasi SPS UPI.

[19] Yang, K.; Zhang, Y. \& Holzer, M. (2008). dealing with Multiple Paradigms in Public Administration Research; in Handbook of research methods in public administration / editors: Gerald J. Miller and Kaifeng Yang; Taylor \& Francis Group, LLC. 